Abstracta Iranica Abstracta Iranica

Revue bibliographique pour le domaine irano-aryen

Volume 22 | 2001

Comptes rendus des publications de 1999

\title{
Caucasus: War and Peace. The New World Disorder and Caucasia. Harlem, SOTA, 1998, 222 p., cartes.
}

\section{Rédaction}

\section{(2) OpenEdition}

1 Journals

Édition électronique

URL : http://journals.openedition.org/abstractairanica/37295

DOI : 10.4000/abstractairanica.37295

ISSN : 1961-960X

\section{Éditeur :}

CNRS (UMR 7528 Mondes iraniens et indiens), Éditions de l'IFRI

\section{Édition imprimée}

Date de publication : 15 mai 2001

ISSN : 0240-8910

\section{Référence électronique}

Rédaction, "Caucasus: War and Peace. The New World Disorder and Caucasia. Harlem, SOTA, 1998, 222 p., cartes. », Abstracta Iranica [En ligne], Volume 22 | 2001, document 625, mis en ligne le 17 février 2010, consulté le 13 octobre 2020. URL : http://journals.openedition.org/abstractairanica/37295 ; DOI : https://doi.org/10.4000/abstractairanica.37295

Ce document a été généré automatiquement le 13 octobre 2020.

Tous droits réservés 
Caucasus: War and Peace. The New World Disorder and Caucasia. Harlem, SOTA, 1998, 222 p., cartes.

Rédaction

For a detailed account, see the review by Hovann H. Simonian in CAS, 18/3 (1999), pp. 393-398.

INDEX

Thèmes : 13.3. Asie centrale

AUTEURS

RÉDACTION

Directeur de la revue et secrétariats (Paris et Téhéran) 